\title{
HEPATIC HYPERPLASIA AND DAMAGES INDUCES BY ZEARALENONE Fusarium Mycotoxins in BALB/c Mice
}

\author{
Pronobesh CHATOPADHYAY, Anurag PANDEY, \\ Asshwani K. CHAURASIA, Addesh UPADHYAY, \\ Sanjev KARMAKAR and Lokendra SINGH
}

\begin{abstract}
Context - Zearalenone is a mycoestrogen and considered a mycotoxin. Objective - To establish whether zearalenone produced hepatotoxicity via oral administration. Methods - Zearalenone was orally administered at a dose of $50 \mu \mathrm{g}, 100 \mu \mathrm{g}$ and $200 \mu \mathrm{g}$ ZEN/ body weight/daily, respectively, for 14 days to three groups of BALB/c mice. Diagnostic modalities used to evaluate hepatic damage and impaired hepatic function pre- and post zearalenone administration included hepatic marker enzyme activity, pentobarbital sleeping time, cytochrome $\mathrm{P}_{450}$ activities and histopathologic evaluation of liver. Results - Significant histopathologic changes viz. sinusoidal congestion, cytoplasmic vacuolization, hepatocellular necrosis and neutrophil infiltration were observed after evaluating of liver section from each group after accumulated zearalenone exposure. Further, zearalenone exposure increased activities of alanine transaminase, aspartate transaminase and lipid peroxides whereas activities of tissue glutathione and cytochrome $\mathrm{P}_{450}$ were decreased as compared to control mice. Zearalenone also increased the sleeping time and decreased sleeping latency after pentobarbital through intraperitoneal route as compared to control mice which indicates that the impairment of hepatic metabolizing enzymes by zearalenone. Conclusion - Zearalenone is a potential hepatotoxin by oral route.

Headings - Zearalenone. Hyperplasia. Liver, pathology. Mice.
\end{abstract}

\section{INTRODUCTION}

Zearalenone (6-[10-hydroxy-6-oxo-trans-1-undecenyl]Bresorcyclic acid lactone) (ZEN), is a non-steroidal mycoestrogen that activates the estrogen receptors (ERs), ESR 1 and ESR2, where it acts as an agonist and partial antagonist to estradiol ${ }^{(5,8,10)}$. ZEN also reported that facilitates carcinogenesis, reproductive toxicity ${ }^{(10)}$ and suppress immunity ${ }^{(9)}$. ZEN contaminated of cereals and grains and related products causes food and feed-borne intoxications (myco-toxicoses) in man and livestock. This mycotoxins produces by various members of the genus Fusarium, including deoxynivalenol (mostly produced by $F$. graminearum and $F$. sporotrichoides) and zearalenone (produced by $F$. graminearum and $F$. culmorum among others) which are major concern in health.

Most of its biological activities of ZEN are attributed to the agonist effect on the ER and certain biological reactions of zearalenone that can not be explained by its estrogenic activity ${ }^{(5)}$. Estrogens taken by women for birth control purposes are implicated as a cause for development of both benign and malignant hepatic neoplasms ${ }^{(11,12)}$. In addition to endogenous steroidal estrogens, a variety of compounds with estrogenic activity also are found in the environment because a number of drugs, insecticides, and natural food products representing many different structures can act like estrogens by products by first phase metabolic transformation after ingestion. Therefore estrogenic activities of ZEN have possibilities to extend the other biological effects - hepatotoxicity.

The aim of the research was to examine the toxic influence of ZEN on liver through estimating mycotoxin influence on markers evaluating hepatic damage.

\section{METHODS}

\section{Animals and housing conditions}

All the born in the laboratory breeding colony of Central Facility of Animal House, Defence Research Laboratory Tezpur, Assam, India, and maintained under temperature controlled rooms at animal house with $12 \mathrm{~h}$ alternating light and dark cycles. Food was obtained from Pranav Agrotech, Delhi, India. All experimental protocols using animals were performed according to the "Principles of Laboratory Animal care" (NIH publication 85-23, revised 1985) and approved by Institutional Use and Care Committee. 


\section{Study design}

Twenty-four Balb/c mice were divided into control group (I) $(n=6)$ were given $0.9 \%$ saline $(5 \mathrm{~mL} / \mathrm{kg}, \mathrm{p} . \mathrm{o}), \mathrm{ZEN}$ treated groups viz. Groups II, III and IV were given $50 \mu \mathrm{g}, 100 \mu \mathrm{g}, 200 \mu \mathrm{g}$ ZEN/ body weight/daily, respectively, by oral route for 14 days $(n=6)$. After 14 days mice were euthanized by ether inhalation and sacrificed. Blood samples were obtained from the right ventricle via a left anterior thoracotomy and separated serum. The serum samples were stored at $-20^{\circ} \mathrm{C}$ until used for ALT and AST assays. A portion of liver lobes were fixed in buffered 10\% formalin, embedded in paraffin, and used for histopathology by using hematoxylin and eosin (H-E) staining. Another portion of lobe was stored at $-20^{\circ} \mathrm{C}$ for enzymatic assay.

\section{Preparation of mice of liver microsome}

Liver microsome was measured as described by previously ${ }^{(18)}$. Briefly, $100 \mathrm{mg}$ liver was excised and homogenized with a loosefitting Teflon pestle in $900 \mathrm{~mL}$ of $50 \mathrm{mM} \mathrm{L}^{-1}$ Tris-HClbuffer, $\mathrm{pH}$ 7.4, containing $0.3 \mathrm{M} \mathrm{L}^{-1}$ sucrose, $10 \mathrm{mM} \mathrm{L}^{-1}$ DTT, and $10 \mathrm{mM} \mathrm{L}^{-1}$ EDTA. The homogenate was centrifuged at $20,000 \mathrm{x}$ g for $15 \mathrm{~min}$. The supernatant solution was centrifuged at $10,000 \mathrm{x}$ g for $60 \mathrm{~min}$. The microsomal fraction obtained was suspended in a homogenizing medium without DTT and re-centrifuged at $10,000 \mathrm{x}$ g for $60 \mathrm{~min}$. The resulting microsomal fraction was suspended in $0.1 \mathrm{ML}^{-1}$ phosphate buffer $\mathrm{pH}$ 7.4, containing $1 \mathrm{mM} \mathrm{L}^{-1}$ EDTA and volume was adjusted to $10 \mathrm{~mL}$ with phosphate buffer.

\section{Estimation of hepatic marker enzymes}

Serum was used for the assay of alanine transaminase (ALT) and aspartate transaminase (AST) using assay kits (Transasia, Mumbai, India) according to the manufacturer's instructions.

\section{Determination of cytochome $\mathbf{P}_{450}\left(\right.$ CYP $\left._{450}\right)$}

Hepatic cytochome $\mathrm{P}_{450}$ was measured as described by previously ${ }^{(16)}$. Briefly $1 \mathrm{~mL}$ supernatant of liver microsomes was taken and $10 \mathrm{mg}$ of sodium dithionate was added. Air was bubbled for 10 seconds and then centrifuged for 5 minutes at $3000 \mathrm{x}$ g. Five hundred $\mu \mathrm{l}(500 \mu \mathrm{l})$ supernatant was mixed with $5 \mathrm{~mL}$ Tris $\mathrm{HCl}$ buffer ( $\mathrm{pH}$ 7.4) and absorbance was measured at $450 \mathrm{~nm}$ wavelengths using excitation coefficient of $91 \mathrm{~mol}$ $\mathrm{L}^{-1} \mathrm{~cm}^{-1}$ for $\mathrm{A}_{450}$.

\section{Light microscopy analysis}

Six $\mu \mathrm{m}$ stains of formalin -fixed and paraffin-embedded were taken and stained with H-E. Slide was examined by a pathologist who had no prior knowledge of the treatment groups. Histopathology of liver was evaluated by using a scoring system (Table 1) as described previously ${ }^{(19)}$.

Two types of eosinophilic hepatocellular changes are presumed to be apoptotic in origin viz. round and detached from surrounding hepatocytes (classical Councilman bodies) and shrunken compared to adjacent hepatocytes, but still firmly attached were counted in 5 to 20 fields from each liver to count at least 100 stellate $-\mathrm{Abs}$. The changes in stellate cells were calculated by using a scoring system.
TABLE 1. Scale of histopathology scoring

\begin{tabular}{lc}
\hline \multicolumn{1}{c}{ Histopathology } \\
\hline Assessment & Score \\
\hline Steatosis (the percentage of liver cells (containing) & $1+$ \\
$5 \%$ to $25 \%$ of cells containing fat & $2+$ \\
$26 \%$ to $50 \%$ of cells containing fat & $3+$ \\
$51 \%$ to $75 \%$ of cells containing fat & $4+$ \\
$>75 \%$ of cells containing fat & \\
Inflammation and necrosis & $1+$ \\
One focus/ lobule & $2+$ \\
Two or more foci/ lobules & $3+$ \\
Apoptosis & \\
Stellate cells & $1+$ \\
If nucleus fragmented present or absent & $2+$ \\
If nucleus Pyknotic (or those in intact nuclei) & $3+$ \\
If nucleus Pyknotic, fragmented or absent & $4+$ \\
If adjacent inflammation present & $5+$ \\
If located in an acidophilic domain & $6+$ \\
If nodular hyperplasia & \\
If atrophy present & \\
If necrosis present & \\
If apoptosis present & $5+$ \\
\hline
\end{tabular}

\section{Determination of lipid peroxides (LPO)}

Hepatic LPO was measured as method described ${ }^{(7)}$. To $100 \mu$ separated microsomes in $0.1(\mathrm{M})$ phosphate buffer saline, $1 \mathrm{~mL}$ of $28 \%$ trichloroacetic acid was added and centrifuged at $\times 2000 \mathrm{~g}$ at $4^{\circ} \mathrm{C}$ for 20 minutes. One milliliter of supernatant was separated and $900 \mu \mathrm{l}$ of $1 \%$ thiobarbituric acid was added and volume was adjusted to $3 \mathrm{~mL}$ by using phosphate buffer ( $\mathrm{pH}$ 7.0), heated in water bath for $60 \mathrm{~min}$ and cooled in ice bath. The absorbance was measured at $532 \mathrm{~nm}$. The lipid peroxidation was calculated on the basis of the molar extinction coefficient $\left(1.56 \times 10^{5}\right)$ of malondialdehyde.

\section{Tissue glutathione (GSH) assays}

The hepatic reduced GSH level was determined by the method of Ellman ${ }^{(2)}$. Briefly, after $0.2 \mathrm{~g}$ liver tissues were homogenized in $4 \mathrm{~mL}$ of $0.02 \mathrm{M}$ EDTA Na2 (using an all glass homogenizer in an ice bath). In $2.5 \mathrm{~mL}$ tissue homogenates (aliquots) were mixed with $2.0 \mathrm{~mL}$ of distilled water and $0.2 \mathrm{~mL}$ of $50 \%$ TCA. All tubes were shaken intermittently for 10-15 min and centrifuged for $15 \mathrm{~min}$ at approximately $3000 \times \mathrm{g}$. Two milliliter of $0.4 \mathrm{M}$ Tris buffer ( $\mathrm{pH} 8.9$ ) and $0.1 \mathrm{~mL}$ of $0.01 \mathrm{M} \mathrm{5,5}$ dithiobis-2-nitrobenzoic acid (DTNB) were added to 2.0 $\mathrm{mL}$ of tissue supernatant, and the sample was shaken. The absorbance was read within 5 min of the addition of DTNB at $412 \mathrm{~nm}$ against a reagent blank with no homogenate. GSH levels were calculated using standard curve prepared by known amounts of GSH (Aldrich Chemical Co. Ltd, Germany). The concentration of GSH was expressed as $\mathrm{mg} / \mathrm{g}$ tissue. 


\section{Pentobarbital sleeping time}

The pentobarbital sleeping time test was performed using pentobarbital. After 14 days treatment with ZEN animals received pentobarbital (concentration of $3 \mathrm{~g} / 100 \mathrm{~mL}$ of solution) through intraperitoneal injection at a dosage of $50 \mathrm{mg} / \mathrm{kg}$ of mice body weight (or $0.0017 \mathrm{~mL} / \mathrm{g}$ of animal weight) and time was measured in minutes, from the loss of position reflex to its gaining reflexes.

\section{Statistical analysis}

Data are expressed as mean \pm S.D. The statistical significance between data means was determined by Student's $t$-test. $P$-values $P<0.05$ were considered as significant

\section{RESULTS}

\section{Effect of ZEN on hepatic marker enzymes and cytochrome $\mathbf{P}_{450}$}

ZEN increases significantly $(P<0.01)$ AST, ALT levels whereas cytochrome $\mathrm{P}_{450}$ levels decreases as compared to controlled mice. Activities of ALT and AST were 55.23 \pm 7.1 and $52.19 \pm 9.40 \mathrm{I} \mathrm{UL}^{-1}$, respectively, in controlled mice which increased to $87.96 \pm 4.64$ and $70.33 \pm 3.59$. $\mathrm{UL}^{-1}$, respectively, in ZEN treated $(200 \mu \mathrm{g} / \mathrm{kg}$ body weight) mice.

Microsomal, cytochrome $\mathrm{P}_{450}$ levels in the control mice were $0.66 \pm 0.032 \mathrm{nML}^{-1} \mathrm{mg}^{-1}$ proteins which decreased to $0.29 \pm 0.017 \mathrm{nML}^{-1} \mathrm{mg}^{-1}$ proteins after treatment for 14 days with ZEN $200 \mu \mathrm{g} / \mathrm{kg}$ body weight (Table 2).

\section{Effect of ZEN on LPO, GST, sleeping time and sleep latency}

After treatment with ZEN significantly $(P<0.01)$ increased LPO levels and GST levels were significantly decreased $(P<0.01)$ as compared to control group. Activities of LPO and GST were $0.7 \pm 0.05 \mathrm{nML}^{-1} \mathrm{MDA} \mathrm{mg}^{-1}$ of protein and $52.40 \pm 4.90 \mathrm{mM} \mathrm{L}^{-1}$ of 1-chloro 2,4-dinitrobenzene (CDNB) conjugated $\mathrm{min}^{-1} 100 \mathrm{mg}^{-1}$ protein in control groups and after treatment with ZEN (200 $\mu \mathrm{g} / \mathrm{kg}$ body weight) increased to $5.22 \pm 0.80 \mathrm{nML}^{-1} \mathrm{MDA} \mathrm{mg}^{-1}$ of protein whereas GST decreased to $36.20 \pm 3.77 \mathrm{mM} \mathrm{L}^{-1}$ of 1-chloro 2,4-dinitrobenzene (CDNB) conjugated $\min ^{-1} 100 \mathrm{mg}^{-1}$ protein.

Microsomal, cytochrome $\mathrm{P}_{450}$ levels in the control mice were $0.66 \pm 0.032 \mathrm{nML}^{-1} \mathrm{mg}^{-1}$ proteins which decreased to $0.29 \pm 0.017 \mathrm{nML}^{-1} \mathrm{mg}^{-1}$ proteins after treatment for 14 days with ZEN $200 \mu \mathrm{g} / \mathrm{kg}$ body weight (Table 3). Pentobarbital along with ZEN increased significantly $(P<0.01)$ sleeping time as compared to control mice (Table 4).

\section{Effect of ZEN on liver histopathology}

Liver histopathology was evaluated based on sinusoidal congestion, cytoplasmic vacuolization, hepatocellular necrosis, and neutrophil infiltration (Table 5). Histopathology examination of liver sections of control group showed normal cellular architecture with distinct hepatic cells, sinusoids spaces and central vein (Figure 1a). ZEN treated group showed that disarrangement and degeneration of normal hepatic cells with intense centri-lobular necrosis extending to mid-zone and sinusoidal hemorrhages and dilation.

TABLE 2. The effect of ZEN on ALT, AST, cytochrome $\mathrm{P}_{450}$ levels after 14 days treatment

\begin{tabular}{|c|c|c|c|}
\hline Groups & ${ }^{\mathrm{a}} \mathrm{ALT}$ & ${ }^{\mathrm{a} A S T}$ & ${ }^{\mathrm{b}}$ Cytochrome $\mathbf{P}_{450}$ \\
\hline Control mice (Group I) & $55.23 \pm 7.10$ & $52.19 \pm 9.40$ & $0.66 \pm 0.032$ \\
\hline ZEN treated (Group II) $(50 \mu \mathrm{g} / \mathrm{kg}$ body weight $)$ & $62.11 \pm 5.32 *$ & $60.73 \pm 4.47 *$ & $0.50 \pm 0.047$ \\
\hline ZEN treated (Group III) (100 $\mu \mathrm{g} / \mathrm{kg}$ body weight) & $70.33 \pm 6.91 *$ & $64.77 \pm 5.06 *$ & $0.33 \pm 0.053 *$ \\
\hline ZEN treated (Group IV) $(200 \mu \mathrm{g} / \mathrm{kg}$ body weight $)$ & $87.36 \pm 4.64 *$ & $70.33 \pm 3.59 *$ & $0.29 \pm 0.017 *$ \\
\hline
\end{tabular}

Results are expressed as mean $\pm \mathrm{SD}(\mathrm{n}=6)$. *Statically different $(P<0.01)$ from control. ${ }^{a}$ Expressed in I.U. $\mathrm{L}^{-1}$, ${ }^{\mathrm{b}}$ Expressed as $\mathrm{nML}^{-1} \mathrm{protein}$

TABLE 3. The effect of ZEN on GST and LPO after 14 days oral administration

\begin{tabular}{lcc}
\hline Groups & ${ }^{\mathrm{a} G S T}$ & ${ }^{\mathrm{a}}$ LPO \\
\hline Control mice (Group I) & $52.40 \pm 4.90$ & $0.7 \pm 0.05$ \\
ZEN treated (Group II) $(50 \mu \mathrm{g} / \mathrm{kg}$ body weight) & $43.27 \pm 6.66$ & $2.36 \pm 0.77$ \\
ZEN treated (Group III) $(100 \mu \mathrm{g} / \mathrm{kg}$ body weight) & $40.16 \pm 2.75$ & $3.56 \pm 0.82$ \\
ZEN treated (Group IV) $(200 \mu \mathrm{g} / \mathrm{kg}$ body weight) & $36.20 \pm 3.77$ & $5.22 \pm 0.80$ \\
\hline
\end{tabular}

Results are expressed as mean $\pm \mathrm{SD}(\mathrm{n}=6)$. $*$ Statically different $(P<0.01)$ from control. ${ }^{\mathrm{a}}$ Expressed as $\mathrm{nM} \mathrm{L}{ }^{-1}$ of 1 -cloro 2,4 -dinitrobenzene $(\mathrm{CDNB})$ conjugated min ${ }^{-1} 100 \mathrm{mg}^{-1}$ protein for GST; ${ }^{b}$ Expressed as $\mathrm{nML}^{-1} \mathrm{MDA} \mathrm{mg^{-1 }}$ of protein

TABLE 4. The effect of ZEN on sleeping time and sleep latency after 14 days oral administration of pentobarbital

\begin{tabular}{|c|c|c|}
\hline Groups & Duration of sleep time & Sleep latency \\
\hline Control mice + Phenobarbitone (Group I) & $80.02 \pm 2.77$ & $2.84 \pm 0.88$ \\
\hline ZEN treated + Phenobarbitone (Group II) $(50 \mu \mathrm{g} / \mathrm{kg}$ body weight) & $91.54 \pm 3.56^{*}$ & $2.35 \pm 0.54^{*}$ \\
\hline ZEN treated + Phenobarbitone (Group III) $(100 \mu \mathrm{g} / \mathrm{kg}$ body weight) & $107.89 \pm 9.23^{*}$ & $2.33 \pm 0.47$ \\
\hline ZEN treated + Phenobarbitone (Group IV) $(200 \mu \mathrm{g} / \mathrm{kg}$ body weight) & $125.64 \pm 11.54 *$ & $1.97 \pm 0.75 *$ \\
\hline
\end{tabular}

Results are expressed as mean $\pm \mathrm{SD}(\mathrm{n}=6)$. $*$ Statically different $(P<0.01)$ from control. Sleep time, sleep latency were expressed in minutes 
TABLE 5. The effect of ZEN on histopathology of liver after 14 days oral administration

\begin{tabular}{|c|c|c|c|c|}
\hline \multirow{3}{*}{ Histopatological features } & \multicolumn{4}{|c|}{ Groups } \\
\hline & \multicolumn{2}{|c|}{ Control groups } & \multicolumn{2}{|c|}{ ZEN treated groups } \\
\hline & Round AB & Stellate AB & Round AB & Stellate AB \\
\hline a. Nucleus fragmented or absent & $5 / 105(5 \%)$ & $15 / 400(4 \%)$ & $77 / 189(41 \%)$ & $59 / 510(12 \%)$ \\
\hline b. Nucleus Pyknotic (intact nucleus) & $4 / 110(4 \%)$ & $13 / 200(7 \%)$ & $40 / 70(57 \%)$ & $190 / 620(31 \%)$ \\
\hline c. Nucleus Pyknotic fragmented or absent & Not significant & $1 / 125(2 \%)$ & $102 / 140(72 \%)$ & $240 / 550(44 \%)$ \\
\hline d. Adjacent inflammation present & Not significant & Not significant & $87 / 109(80 \%)$ & $222 / 487(46 \%)$ \\
\hline e. Located in an acidophilic domain & $2 / 108(2 \%)$ & $6 / 330(2 \%)$ & $104 / 188(55 \%)$ & $98 / 175(56 \%)$ \\
\hline f. Nodular hyperplasia & $4 / 125(3 \%)$ & $17 / 220(8 \%)$ & $103 / 127(81 \%)$ & $104 / 125(83 \%)$ \\
\hline g. Atrophy & $4 / 116(3 \%)$ & $4 / 155(3 \%)$ & $105 / 160(66 \%)$ & $69 / 104(66 \%)$ \\
\hline
\end{tabular}

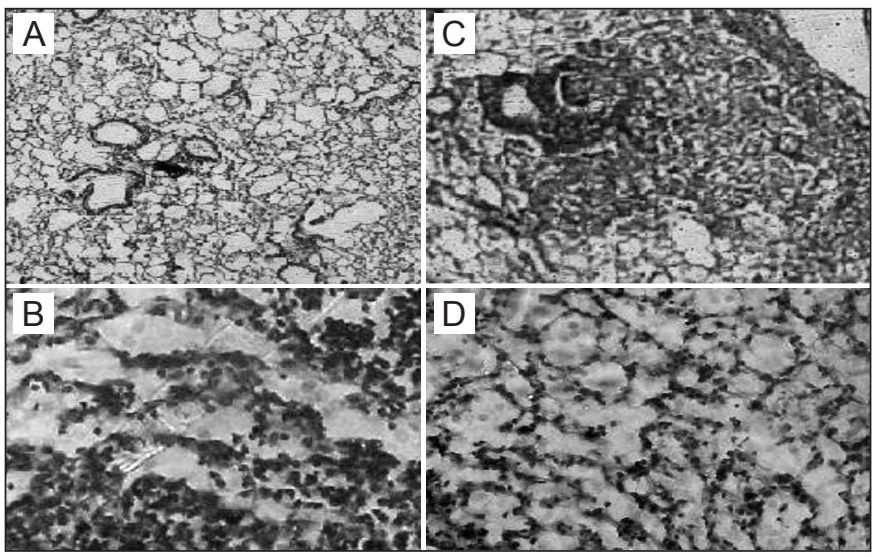

FIGURE 1. Showing histopathology of liver sections after staining with H-Eosin (H-E, x.400). (A) Liver section of control mice showing normal architecture of liver with central vein. (B) Liver section of ZEN (50 $\mu \mathrm{g} / \mathrm{kg}$ body weight) administered showing sinusoidal congestion and cytoplasmic vacuolization. (C) Liver section of ZEN (100 $\mu \mathrm{g} / \mathrm{kg}$ body weight) administered showing hepatocellular necrosis and neutrophil infiltration. (D) Liver section of ZEN ( $200 \mu \mathrm{g} / \mathrm{kg}$ body weight) administered showing severe nodular hyperplasia, pyknotic nucleus and necrosis

There was chronic inflammatory cells infiltrate in the portal tracks. There was also extensive hepatocellular necrosis, sinusoidal congestion, and neutrophil infiltration. Shrunken acidophilic hepatocytes were both round and detached from surrounding hepatocytes (round - Abs) and stellate - shaped firmly attached to adjacent hepatocytes (stellate - Abs). In $44 \%$ of round - Abs, the nucleus was fragmented or absent and among those with an intact nucleus, $80 \%$ had nuclear pyknosis stellate. Stellate - Abs often clustered in acidophilic domain usually without significant lymphoid infiltrate or necrosis. Round- Abs were usually not clustered and seen more often with an adjust lymphocytes infiltrate. Also apoptotic bodies, in the form of round or stellate - Abs, were seen (Figure 1b).

\section{DISCUSSION}

In this present investigation ZEN showed hepatotoxicity in $\mathrm{BALB} / \mathrm{c}$ mice which characterized by increasing of hepatic marker enzymes (ALT, AST), decreasing of microsomal cytochrome $\mathrm{P}_{450}$ and histopathology study showed that ZEN decreased in the number of perfused sinusoids and hepatocellular hypoxia.

Zearalenone is resorcylic acid lactones and functionally is mycoestrogen which found in contaminating grain. Mycoestrogen increased incidence of adenomas (pituitary, liver) was detected in one species after a 2-yr oral carcinogenicity study ${ }^{(11)}$. In present investigation ZEN shows the potential hepatotoxicant may due to estrogenic property. Thus, the impaired hepatic function caused after administration of ZEN, that might be a reason for activation of hepatocytes led to increase hepatic marker enzymes, as seen in the present work. The pathophysiology of hepatic injury is complex and it is thought that hepatotoxin activates hepatic cells and subsequently causes free radical- mediated tissue injury and by series of chain reactions produces Lipid peroxidation (LPO) ${ }^{(17)}$ (Figure 1).

Ayed et al. (1) reported the genotoxicity of ZEN and concluded that biotransformation of ZEN involved only partial detoxification and remaining metabolites are relatively toxic. Another study of Frizzell et al. ${ }^{(3)}$ reported that ZEN and its metabolites showed potential endocrine disruptors by altering hormone production. Further, ZEN ingestion of animals from contaminated feed decreased the TNF- $\alpha$ synthesis and IL-8 synthesis ${ }^{(14)}$. Another study of Marin et al. ${ }^{(13)}$ reported similar immunosuppressive effects of ZEN and its derivatives (alpha-ZOL, beta-ZOL, ZAN) in swine. Thus, ZEN showed multiple side effects and our observation reported first time hepatotoxicity of ZEN.

Formation of LPO leads to many pathological changes in tissue including liver necrosis ${ }^{(6)}$. The consequences of lipid peroxidation may be manifested as alternation in membrane integrity of membrane- associated functions in sub-cellular organelles. Reduced glutathione (GSH) is known to function as an antioxidant and a physiological reservoir for cysteine and is involved in DNA synthesis, protein synthesis regulation, and detoxification, etc. Cellular GSH deficiency affects the mitochondrial GSH pool and the cytosolic GSH pool. Mitochondrial GSH is important for the detoxification of ROS generated by the respiratory chain, conjugation of xenobiotics, maintenance of thiol-containing proteins, and regulation of the mitochondrial membrane potential ${ }^{(15)}$ (Table 5). 
In our present study indicates that in parallel increased AST and ALT, increased levels of LPO and decreased GSH activity occurred liver injury by ZEN.

Another point to be considered in this context is that there are increased sleeping times of pentobarbital with combination of ZEN. This result indicates that ZEN impaired metabolism of pentobarbital by hepatic damage with inhibits the activity of CYP ${ }_{450}$. Previous study shows that ZEN activates the nuclear receptor PXR and induces the expression of the drug-metabolizing enzyme CYP3A4, a hepatic monooxygenase involved in the metabolism of about $60 \%$ of clinically used drugs ${ }^{(4)}$. Further, in our present investigation decreased of $\mathrm{CYP}_{450}$ activities correlates the increasing sleeping time of pentobarbital. Thus, it is likely that ZEN inhibits $\mathrm{CYP}_{450}$ activities by hepatotoxicity.
In summary, the present study provides the first functional anatomical evidence that phenobarbitone sleep time increase may predispose the liver to significant oxidative injury and subsequently hepatic damage, $\mathrm{CYP}_{450}$ deactivation by ZEN. Although the detailed mechanisms concerning the deactivation of $\mathrm{CYP}_{450}$ are not fully understood, the current findings present important insights into the potential detrimental effect of oxidative stress and impaired hepatic function of ZEN.

\section{ACKNOWLEDGEMENTS}

This work has been supported by a grant of Defence Research Development Organization (DRDO), Ministry of Defence, Government of India.

Chatopadhyay P, Pandey A, Chaurasia AK, Upadhyay A, Kamarkar S, Singh L. Hiperplasia e danos hepáticos induzidos por micotoxinas do gênero Fusarium-zearalenone em camundongos BAB/c. Arq Gastroenterol. 2012;49(1):77-81.

RESUMO - Contexto - Zearalenone é um micoestrógeno e considerado como micotoxina. Objetivo - Avaliar se o Zearalenone produz hepatotoxicidade por administração via oral. Métodos - Zearalenone foi administrada por via oral em doses de $50 \mu \mathrm{g}, 100 \mu \mathrm{g}$ e $200 \mu \mathrm{g} /$ peso corporal/dia/14 dias, respectivamente, para três grupos de camundongos BAB/C. Modalidades diagnósticas usadas para avaliar o dano hepático e comprometimento da função hepática pré- e pós-administração de Zearalenone incluíram atividade enzimática de marcadores hepáticos, tempo de sono por pentobarbital, atividade do citocromo P-450 e avaliação histopatológica hepática. Resultados - Alterações histopatológicas significantes como congestão sinusoidal, vacuolização citoplasmática, necrose hepatocelular e infiltração neutrofílica foram observadas após avaliação histológica de cada grupo após exposição acumulada de Zearalenone. Além disto, a exposição à Zearalenone incrementou a atividade das enzimas alanina transaminase e aspartato transaminase e peróxidos lipídicos, ao passo que as atividades teciduais de glutationa e citocromo P-450 diminuiram, quando comparadas com camundongos-controle. Zearalenone também aumentou o tempo de sono e diminuiu a latência do sono após a administração de pentobarbital por via intra-abdominal, quando comparados com camundongos-controle, o que indica o comprometimento das enzimas do metabolismo hepático por ela. Conclusão - Zearalenone é uma potente hepatotoxina quando administrada por via oral.

DESCRITORES - Hiperplasia. Zearalenona. Fígado, patologia. Camundongos.

\section{REFERENCES}

1. Ayed Y, Ayed-Boussema I, Ouanes Z, Bacha H. In vitro and in vivo induction of chromosome aberrations by alpha- and beta-zearalenols: comparison with zearalenone. Mutat Res. 2011 [in press].

2. Ellman GL. Tissue sulfhydryl groups. Arch Biochem Biophys. 1959;82:70-7.

3. Frizzell C, Ndossi D, Verhaegen S, Dahl E, Eriksen G, Sorilie M, Ropstad E, Muller M, Elliott Ct, Connolly L. Endocrine disrupting effects of zearalenone, alphaand beta-zearalenol at the level of nuclear receptor binding and steroidogenesis. Toxicol Lett. 2011;206:210-7.

4. Guengerich FP. Cytochrome P-450 3A4: regulation and role in drug metabolism. Annu Rev Pharmacol Toxicol. 1999;39:1-17.

5. Hidy PH, Baldwin RS, Greasham RL, Keith CL, McMullen JR. Zearalenone and some derivatives: production and biological activities. Adv Appl Microbiol. 1977;22:59-82.

6. Jaeschke H, Farhood A. Neutrophil and kupffer cell-induced oxidant stress and ischemic-reperfusion injury in rat liver. Am J Physiol. 1991;260:G355-G62.

7. Jordan RA, Schenkman JB. Relationship between malondialdehyde production and arachidonate consumption during NADPH supported microsomal lipid peroxidation. Biochem Pharmacol. 1982;31:1393-400.

8. Katzenellenbogen BS, Korach KS. A new actor in the estrogen receptor dramaenter ER-beta. Endocrinology. 1997;138:861-2.

9. Kilakivi-Clarke L, Cho E, Onojafe I, Raygada M, Clarke R. Maternal exposure to genistein during pregnancy increases carcinogen-induced mammary tumorgenesis in female rat offspring. Oncol Rep. 1999;6:1089-95.

10. Kuiper GG, Lemmen JG, Carlsson B, Corton JC, Safe SH, van der Saag PT, van der Burg B, Gustafsson JA. Interaction of estrogenic chemicals and phytoestrogens with estrogen receptor beta. Endocrinology. 1998;139:4252-63.

11. La Vecchia C, Negri E, Parazzini F. Oral contraceptives and primary liver cancer. Br J Cancer. 1989;59:460-1.

12. Mant JW, Vessey MP. Trends in mortality from primary liver cancer in England and Wales 1975-92: influence of oral contraceptives. Br J Cancer. 1995;72:800-3.

13. Marin DE, Taranu I, Burlacu R, Tudor DS. Effects of zearalenone and its derivatives on the innate immune response of swine. Toxicon. 2010;56:956-63.

14. Marin DE, Taranu I, Burlacu R, Manda G, Motiu M, Neagoe I, Dragomir C, Stancu M, Calin L. Effects of zearalenone and its derivatives on porcine immune response. Toxicol In Vitro. 2011;25:1981-8.

15. Marubayashi S, Dohi K, Ochi K, Kawaski T. Role of free radicals in ischemic rat liver cell injury: prevention of damage by alpha-tocopherol administration. Surgery. 1986;99:184-2

16. Omura T, Sato R. The carbon monoxide-binding pigment of liver microsomes. I. Evidence for its hemoprotein nature. J Biol Chem. 1964;239;2370-8.

17. Salah-Abbès J, Abbès S, Ouanes Z, Houas Z, Abdel-Wahhab MA, Bacha H, Oueslati R. Tunisian radish extract (Raphanus sativus) enhances the antioxidant status and protects against oxidative stress induced by zearalenone in Balb/c mice. J Appl Toxicol. 2008;28:6-14.

18. Schenkman JB, Cinti DL. Preparation of microsomes with calcium. Methods Enzymol. 1978;52:83-9.

19. Shimamatsu K, Wanless IR. Role of ischemia causing apoptosis, athropy and nodular hyperplasia in human liver. Hepatology. 1997;26:343-50.

Received 1/9/2011. Accepted 20/9/2011. 